\title{
Extracellular Cyclic AMP-Phosphodiesterase Accelerates Differentiation in Dictyostelium discoideum
}

\author{
By FERNANDA ALCÂNTARA* AND G. W. BAZILL† \\ Department of Molecular Biology, University of Edinburgh, Edinburgh EH9 $3 \mathrm{JR}$
}

(Received 14 July 1975)

\begin{abstract}
SUMMARY
Extracellular cyclic AMP-phosphodiesterase accelerates the development of aggregation competence in Dictyostelium discoideum when present during the preaggregation stage. The effect on development appears to depend only on hydrolysis of extracellular cyclic AMP and not on other properties of the phosphodiesterase molecule. Extracellular cyclic AMP-phosphodiesterase, as a promoter of differentiation, acts mainly throughout the first half of interphase. Our evidence supports the proposal that cyclic AMP oscillations control the rate and possibly the initiation of development. Since extracellular cyclic AMP-phosphodiesterase acts from the beginning of interphase cyclic AMP oscillations may also occur from early interphase, at least in the presence of this enzyme. This would imply that the cyclic AMP oscillator is a determinant, but not a product, of the developmental programme.
\end{abstract}

\section{INTRODUCTION}

Unicellular amoebae of Dictyostelium discoideum aggregate to produce a multicellular organism when food becomes scarce. The morphological and biochemical changes which accompany this process have been extensively studied since it affords a simple model system for the study of differentiation (Raper, 1950; Gerisch, I968; Newell, I97I ; Ashworth, 197I).

During aggregation the amoebae move toward each other in response to a chemical attractant which is almost certainly cyclic AMP (c-AMP) (Konijn et al., I968; Barkley, I969; Roos et al., I 975). Some of the steps in the developmental programme therefore concern the production and detection of c-AMP: the number of binding sites for c-AMP increases (Bonner et al., 1969; Malchow \& Gerisch, 1974) and cells develop the ability to relay signals, i.e. to emit a pulse of c-AMP, after detecting one from a neighbouring cell (Shaffer, I957; Gerisch, 1968; Robertson, Drage \& Cohen, I972). Release of c-AMP (Malkinson \& Ashworth, 1973) and of a rate substance inducing chemotaxis (Bonner, Kelso \& Gillmor, 1966) occurs in interphase although spontaneous oscillations in extracellular c-AMP concentrations have been detected only in the late pre-aggregation stage (Gerisch \& Hess, I974; Roos et al., 1975). The activity of membrane-bound c-AMP-phosphodiesterase (PDE) increases during pre-aggregation and aggregation; the activity of the extracellular form may steadily increase during the same periods or may form an early peak (at $\left.t_{2}\right)$ after interphase has continued for $2 \mathrm{~h}$ depending on the conditions of development (Riedel \& Gerisch, I97I ; Malchow et al., 1972; Malkinson \& Ashworth, 1973). In addition to the development of an autonomous chemotactic system, cells acquire aggregation-specific contact sites at their surface which are involved in stream formation (Beug, Katz \& Gerisch, I973a; Beug et al., I $973 b$ ) and they become more adhesive (Bonner et al., I969). All these changes bring the

* Present address: Labatorio de Biologia, L. Marques University, Lourenço Marques, Mozambique.

$\dagger$ Present address: Paterson Laboratory, Christie Hospital and Holt Radium Institute, Manchester M20 9BX. 
cells to the developmental stage known as aggregation competence. This stage is defined operationally: cells are aggregation competent if they spontaneously form centres of aggregation and streams as soon as they are spread on a suitable surface.

In studies of signal propagation during aggregation, the duration of the interphase stage $\left(t_{\mathrm{agg}}\right)$ depended on cell density: at $5 \times 10^{5} \mathrm{cells} / \mathrm{cm}^{2}$, aggregation began after $6 \mathrm{~h}$, whereas at $5 \times 10^{4}$ cells $/ \mathrm{cm}^{2}$ it began after I3 h (Alcântara \& Monk, 1974; see also Konijn \& Raper, 196I; Konijn, 1968). It was also found (F. Alcântara, unpublished observations) that cells spending $9 \mathrm{~h}$ of interphase at low density were unable to respond to artificial sources of c-AMP. Thus even before aggregation and signal relay had started, the progress of development appeared to depend on some sort of cellular interaction.

One hypothesis to account for the dependence of $t_{\text {agg }}$ on cell density is that accumulation of extracellular factors in the surrounding medium is either required for or stimulates the development of aggregation competence; at low cell densities such factors would accumulate slowly and aggregation would be delayed. In experiments to test this hypothesis, we found that an 'acceleration factor' (AF) was secreted into the medium during interphase. This factor accelerated the development of aggregation competence when added to cells at the beginning of interphase but when added later the effect was less marked. On DEAE chromatography, gel filtration and electrophoresis, the acceleration factor behaved as if it was identical with extracellular c-AMP-phosphodiesterase or very closely associated with it.

\section{METHODS}

Organism. Dictyostelium discoideum strain Ax2 was kindly provided by Professor J. Ashworth.

Media. $\mathrm{KK}_{2}$ buffer contained (g/l water): $\mathrm{KH}_{2} \mathrm{PO}_{4}, 2 \cdot 25 ; \mathrm{K}_{2} \mathrm{HPO}_{4}, 0 \cdot 67 ; \mathrm{MgSO}_{4} \cdot 7 \mathrm{H}_{2} \mathrm{O}$, 0.05 ; pH 6.I. Axenic broth HL5 (Watts \& Ashworth, I970) contained (g/l water): bacteriological peptone (Oxoid), I4.3; yeast extract (Difco), $7 \cdot 15 ; \mathrm{NaH}_{2} \mathrm{PO}_{4} \cdot \mathrm{I}_{2} \mathrm{H}_{2} \mathrm{O}, \mathrm{I} \cdot 28 ; \mathrm{KH}_{2} \mathrm{PO}_{4}$, 0.49; D-glucose, $15 \cdot 4 ; \mathrm{pH} \mathrm{6.7}$. Non-nutrient (NN) agar contained Io g Bacto-agar (Difco) and $\mathrm{I} 1, \mathrm{KK}_{2}$ buffer. Imidazole- $\mathrm{HCl}$ buffer contained $(\mathrm{g} / \mathrm{l}$ water): imidazole, $\mathrm{I} \cdot 37$; $\mathrm{Mg}\left(\mathrm{CH}_{3} \mathrm{COO}\right)_{2} .4 \mathrm{H}_{2} \mathrm{O}, 0.54 ; \mathrm{CaCl}_{2}, 0.06 ; \mathrm{pH} 7 \cdot 0$. Imidazole agar contained $10 \mathrm{~g}$ Bactoagar (Difco) and $\mathrm{I} 1$ imidazole- $\mathrm{HCl}$ buffer.

Optical method. A Wild M 20 microscope equipped with a humidity chamber was used for phase-contrast observations (magnification $\times 125$ ).

Growth conditions and initiation of development. Ax2 cells were grown in HL5 medium at $22{ }^{\circ} \mathrm{C}$ on a rotary shaker ( $160 \mathrm{rev} . / \mathrm{min}$ ). Exponential-phase cells were harvested by centrifugation at $260 \mathrm{~g}$ for I min, washed twice in cold $\mathrm{KK}_{2}$ buffer and resuspended either in cold $\mathrm{KK} 2$ buffer or in cold test solution (see Results). Initiation of interphase $\left(t_{0}\right)$ corresponds to the time of final resuspension, which followed harvesting by no more than $15 \mathrm{~min}$. Aggregation competence was developed in the light at $22{ }^{\circ} \mathrm{C}$ in cells either agitated in suspension or spread on the surface of NN agar ( $5 \mathrm{ml} \mathrm{NN}$ agar freshly poured in $5 \times 8 \mathrm{~cm}$ plastic boxes). $\mathrm{NN}$-agar plates were incubated in humidity chambers provided with glass covers.

Preparation of AF solutions. Ax 2 cells were suspended in $\mathrm{KK}_{2}$ buffer for development in suspension. If not stated otherwise, cell density was $4 \times 10^{7}$ to $8 \times 10^{7} / \mathrm{ml}$. The extracellular medium was collected by centrifugation at $260 \mathrm{~g}$ for $\mathrm{I}$ min followed by another centrifugation at $10000 \mathrm{~g}$ for $20 \mathrm{~min}$, both at $4{ }^{\circ} \mathrm{C}$. The time of collection (in hours) is indicated by the subscript of $t$ : thus, for example, $t_{2}$ means that cells were collected after interphase had continued for $2 \mathrm{~h}, t_{0}$ that cells were collected at the very beginning of interphase as soon as they had been resuspended, and $t_{\text {agg }}$ that cells were collected at the end of interphase, at the onset of aggregation; $t_{\mathrm{agg}}$ is also a measure of the total duration of interphase. 
When required, the supernatants were concentrated at $4{ }^{\circ} \mathrm{C}$ in a Millipore pressure filtration apparatus using a PSCA membrane (nominal retentivity 1000 daltons). These AF solutions were dispensed in small volumes and stored at $-70^{\circ} \mathrm{C}$.

$A F$ assay. When not stated otherwise, freshly harvested cells were suspended in test and control solutions at $5 \times 10^{6}$ to $7 \times 10^{6}$ cells $/ \mathrm{ml}$. Five $10 \mu 1$ replicate samples were taken from each suspension and deposited on freshly poured $\mathrm{NN}$-agar plates. In the assay for rat-brain PDE, imidazole agar was used as substratum instead of KK2 agar. Incubation was according to the conditions described for development. The appearance of the first signals of cell aggregation - the formation of 3 to 4 cell-streams - was monitored by regular microscopic observation. AF activity is represented by the mean value of $t_{\text {agg }}$ (time of onset of aggregation) for each set of replicas in comparison with the mean $t_{\mathrm{agg}}$ for controls.

Coupling of $A F$ to Sepharose. AF solutions were dialysed overnight, at $4{ }^{\circ} \mathrm{C}$ against coupling buffer $(0.05 \mathrm{M}$-sodium borate buffer $\mathrm{pH} 8.0$ containing $0.5 \mathrm{M}-\mathrm{NaCl})$. CNBr-activated Sepharose-4B ( $\mathrm{g}$; Pharmacia) was washed in $\mathrm{I} \mathrm{mm}-\mathrm{HCl}$ and $0.5 \mathrm{~g}$ wet gel was used for coupling AF in each of three $3 \mathrm{ml}$ portions of AF solution. Coupling was carried out at room temperature for $5 \frac{1}{2} \mathrm{~h}$ and then at $4 \mathrm{C}$ overnight. The gels were then washed in coupling buffer and resuspended for $2 \mathrm{~h}$ in I $\mathrm{M}$-ethanolamine- $\mathrm{HCl} \mathrm{pH} 8 \cdot 0$, followed by six rinsing cycles, first with $\mathrm{O} \cdot \mathrm{I} \mathrm{M}$-sodium acetate buffer $\mathrm{pH} 4.0$ containing $\mathrm{I} \mathrm{M}-\mathrm{NaCl}$ and then with $0 . \mathrm{I}$ M-borate buffer $\mathrm{pH} 8.0$ also containing $1 \mathrm{M}-\mathrm{NaCl}$. The gels were washed, resuspended in $\mathrm{KK} 2$ buffer and stored at $4{ }^{\circ} \mathrm{C}$ after addition of $0.02 \%(\mathrm{w} / \mathrm{v}) \mathrm{NaN}_{3}$. A control gel was prepared identically, but omitting the AF coupling step. AF and PDE assays were done with freshly washed gels. For AF assays, $10 / 1$ drops of a suitable gel dilution were deposited on $\mathrm{NN}$-agar plates, allowed to settle and the supernatant removed by suction; cell suspension in KK 2 buffer ( IO $\mu 1$ ) was then placed on the gel layer. For PDE assays the gel was kept in suspension by agitation during the reaction.

Fractionation of $A F$ solution on DEAE cellulose. A six-times concentrated $t_{10}$ AF solution $(55 \mathrm{ml})$ was dialysed overnight against $20 \mathrm{~mm}$-triethanolamine- $\mathrm{HCl}(\mathrm{TEA}-\mathrm{HCl}), \mathrm{pH} 6 \cdot 8$, and applied to a column $(25 \times 2 \mathrm{~cm})$ of Whatman DE 52 cellulose equilibrated with the same buffer. The column was first washed with $50 \mathrm{ml}$ TEA-HCl buffer and then eluted with a gradient of 0.0 to $0.4 \mathrm{M}-\mathrm{KCl}$ in $20 \mathrm{~mm}$-TEA-HCl, $\mathrm{pH} 6.8$. These procedures took place at $4 \mathrm{C}$. Fifty $4 \mathrm{ml}$ fractions were collected and assayed for AF and PDE activities. $E_{280}$ was measured in a Beckman spectrophotometer.

Filtration on Sephadex G200. Following fractionation of an AF solution on DE 52 cellulose, $0.5 \mathrm{ml}$ portions of each fraction within the coincident PDE and AF peaks (fractions 35 to 39) were pooled (total volume $2.5 \mathrm{ml})$ and applied to a column $(55 \times \mathrm{I} .5 \mathrm{~cm})$ of Sephadex G200, with Blue Dextran 2000 and $\mathrm{NaN}_{3}$ as markers. Elution was carried out at $4{ }^{\circ} \mathrm{C}$ with $0.017 \mathrm{M}$-sodium-potassium phosphate buffer $\mathrm{pH} 6 . \mathrm{I}$. Each $\mathrm{I} \cdot 2 \mathrm{ml}$ fraction was assayed for PDE and AF activities and $E_{280}$ measured.

Disc gel electrophoresis. This was carried out in tris-glycine, $\mathrm{pH} 8 \cdot 3 /$ tris- $\mathrm{HCl}, \mathrm{pH} 8 \cdot 8$, polyacrylamide gels $(7 \%, \mathrm{w} / \mathrm{v})$, according to Davis ( 1964$)$. The supernatant from $t_{10}$ cells was concentrated 93 times by pressure filtration on Millipore PSCA filters and dialysed overnight against $50 \mathrm{~mm}$-tris- $\mathrm{HCl}, \mathrm{pH} 6 \cdot 7$. Samples (I00 $\mu \mathrm{I}$ ) containing $340 \mu \mathrm{g}$ protein were applied to $0.5 \times$ I $\mathrm{cm}$ gels together with a bromophenol blue marker. Electrophoresis, at $4{ }^{\circ} \mathrm{C}$, was at $0.5 \mathrm{~mA} / \mathrm{gel}$ for $20 \mathrm{~min}$ and then at $3 \mathrm{~mA} / \mathrm{gel}$. When the tracking dye neared the bottom (after"approximately $2 \mathrm{~h}$ ) the gels were removed and either frozen at $-70{ }^{\circ} \mathrm{C}$ or fixed and stained. For PDE and AF assays the frozen gels were sliced in I mm sections; each section was eluted overnight in $0.5 \mathrm{ml}$ of $10 \mathrm{~mm}-\mathrm{TEA}-\mathrm{HCl}, \mathrm{pH} 6.8$.

Rat-brain PDE. Three rat brains were homogenized and fractionated according to 
Thompson \& Appleman (I97I). After gel filtration on Bio-Rad A I ·5, fractions in the second (later eluting) peak of PDE activity were combined and concentrated ten times by pressure filtration on Diaflo (Amicon) UM2 membranes (retentivity $\geqslant 1000$ daltons). The concentrate was dialysed at $4{ }^{\circ} \mathrm{C}$ against $500 \mathrm{ml}$ imidazole- $\mathrm{HCl}$ buffer for $5 \mathrm{~h}$ with a change of buffer at $2.5 \mathrm{~h}$. The dialysate was clarified by centrifugation at $\mathrm{I} 2000 \mathrm{~g}$ for $\mathrm{I} 0 \mathrm{~min}$ and kept at $4{ }^{\circ} \mathrm{C}$ (freezing inactivated the enzyme). The PDE activity obtained was 50 units $/ \mathrm{ml}$ and the $K_{m}$ value was approximately I $\mu \mathrm{M}$-c-AMP (data not shown).

$P D E$ assay. PDE solution ( $100 \mu \mathrm{l})$ at appropriate dilution was incubated at $35^{\circ} \mathrm{C}$ with c-AMP (approximately $60 \mu \mathrm{M}$ ) in $\mathrm{I} .0 \mathrm{ml} 0.02 \mathrm{M}-\mathrm{TEA}-\mathrm{HCl}, \mathrm{pH} 7.4$, containing $7 \mathrm{~mm}$ $\mathrm{MgCl}_{2}$, Io $\mu \mathrm{g}$ alkaline phosphatase $(350 \mathrm{u} / \mathrm{mg})$ and $10 \mu \mathrm{g}$ adenosine deaminase $(200 \mathrm{u} / \mathrm{mg})$ (Michal \& Bergmeyer, I970). The change of $E_{265}$, read on a Beckman DB-G spectrophotometer, was continuously recorded. One unit of PDE activity is defined here as the amount of PDE hydrolysing I nmo ${ }^{1} \mathrm{c}-\mathrm{AMP} / \mathrm{min}$ at $35^{\circ} \mathrm{C}$.

Alkaline phosphatase and adenosine deaminase were purchased from Boehringer Mannheim, Germany.

$P D E$ inhibitor. A preparation of extracellular PDE inhibitor was obtained by heating $50 \mathrm{ml}$ of $\mathrm{Ax} 2 t_{14}$ supernatant to $80{ }^{\circ} \mathrm{C}$ for $10 \mathrm{~min}$ and then adding ammonium sulphate to $90 \%$ saturation (Riedel et al., 1972). The precipitate was dissolved in $5 \mathrm{ml}$ of $10 \mathrm{mM}$-TEA$\mathrm{HCl}, \mathrm{pH} 6 \cdot 8$, dialysed overnight against the same buffer and stored frozen at $-70^{\circ} \mathrm{C}$. Purified inhibitor was prepared by DE 52 cellulose chromatography of unheated, dialysed supernatant. The fractions with high inhibitor activity were combined and frozen at $-70^{\circ} \mathrm{C}$.

PDE inhibition. This was carried out according to Riedel \& Gerisch (1971).

Protein content. This was determined according to the method of Lowry et al. (I95I).

\section{RESULTS \\ Dependence of $t_{\mathrm{agg}}$ on cell density}

Alcântara \& Monk (I.974) reported the dependence of $t_{\text {agg }}$ on cell density in populations developing in $\mathrm{KK}_{2}$ buffer. Figure I (broken lines) shows the results from three sets of experiments on the variation of $t_{\mathrm{agg}}$ with cell density, in cells suspended at $t_{0}$ in $\mathrm{KK} 2$ buffer. Above $10^{7}$ cells $/ \mathrm{ml}$ the variation of $t_{\text {agg }}$ with density was not significant, but at lower densities $t_{\text {agg }}$ increased steadily from about $4 \frac{1}{2} \mathrm{~h}$ to $14 \mathrm{~h}$.

\section{Time of onset of aggregation in AF-treated cells}

The extracellular medium from aggregation-competent cell suspensions was collected (see preparation of AF solutions). Freshly harvested Ax2 cells were suspended in this medium at from $3 \times 10^{5}$ to $10^{9}$ cells $/ \mathrm{ml}$ and $t_{\text {agg }}$ was determined by microscopic observation (see Methods). Figure I (full lines) shows the results of these experiments. Parallel experiments carried out with the same stock cells suspended in $\mathrm{KK}_{2}$ buffer gave results which are also represented in Fig. I (broken lines).

The difference in duration of interphase between the $\mathrm{KK}_{2}$-treated and the AF-treated cells increased progressively with decreasing cell densities from $\mathrm{I}$ to $8 \mathrm{~h}$. This demonstrated that interphase may be accelerated by a factor(s) present in the extracellular medium of aggregation-competent cultures, now designated as AF solutions.

In the presence of $\mathrm{AF}$ and at $10^{7}$ cells $/ \mathrm{ml}$ or more, the $t_{\mathrm{agg}}$ value was minimal; at less than $10^{7}$ cells $/ \mathrm{ml} t_{\mathrm{agg}}$ increased steadily with decreasing cell density. The assays with different sample volumes (Io and $5 \mu \mathrm{l}$ ) were meant to test the effect of small errors in the volume taken for AF assays. The results showed that at the cell density selected for the standard 


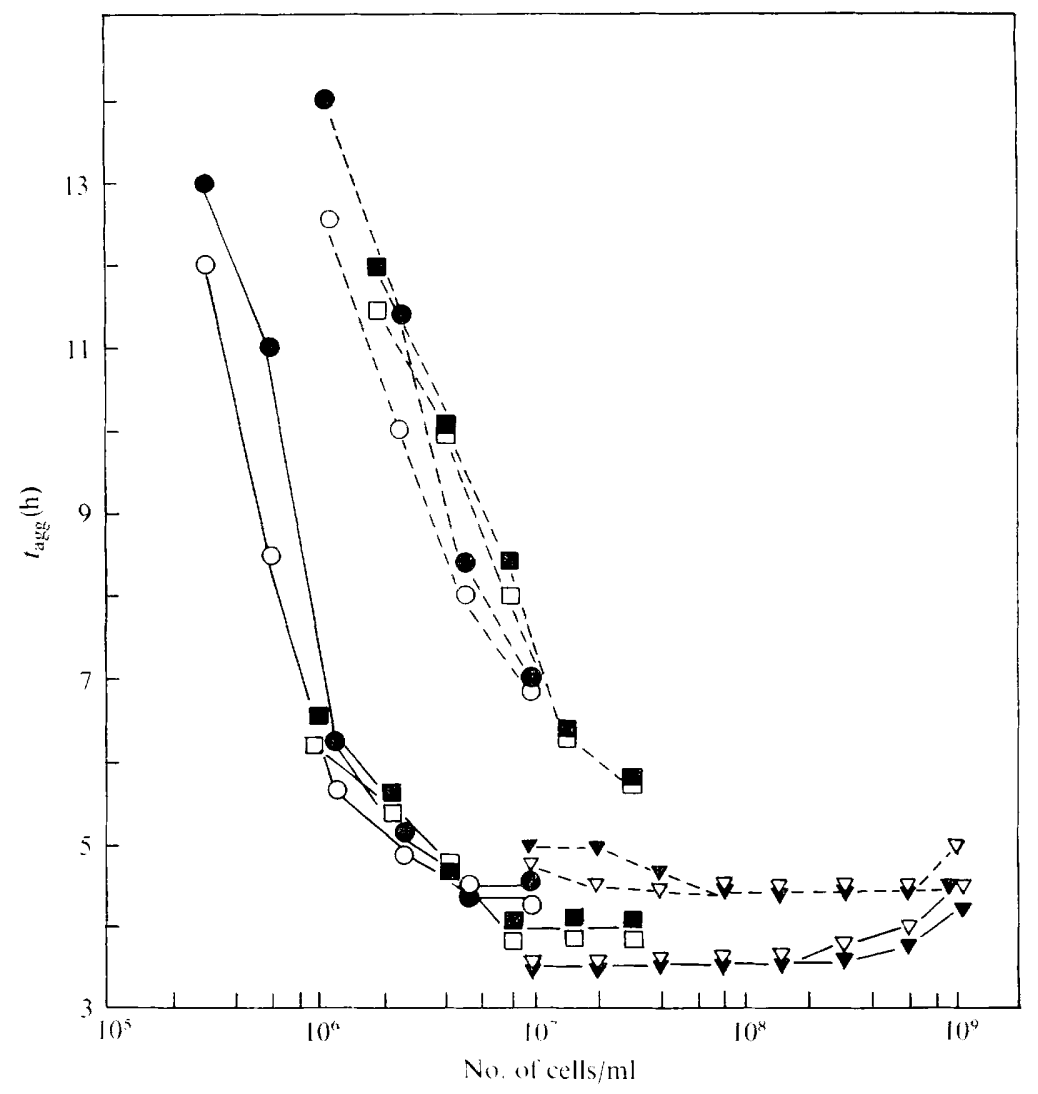

Fig. I. Dependence of $t_{\mathrm{agg}}$ on cell density. Results of three experiments $(\bigcirc, \boldsymbol{\odot} \square, \mathbf{\square} ; \nabla, \nabla)$ are given. Development was initiated in $\mathrm{Ax} 2$ cells suspended in either $\mathrm{KK} 2$ buffer (-- - $)$ or $\mathrm{AF}$ solution (- After adjustment to the desired initial cell density both cell suspensions were successively diluted in the appropriate medium. From the series of cell suspensions samples of Io $\mu \mathrm{l}$ (open symbols) and $5 \mu \mathrm{l}$ (closed symbols) were placed on NN-agar plates and incubated at $22^{\circ} \mathrm{C}$ with illumination. The time of onset of aggregation $\left(t_{\mathrm{agg}}\right)$ was monitored microscopically; points represent the mean $t_{\text {agg }}$ for each set of five replicas (deviation from the mean $\leqslant 15 \mathrm{~min}$ ).

assay $\left(5 \times 10^{6}\right.$ to $7 \times 10^{6}$ cells $\left./ \mathrm{ml}\right)$ small variations in volume and consequently in cell number did not affect $t_{\text {agg }}$. Comparison of populations with the same total number of cells but in which cell density was varied by a factor of 2 , showed that, with populations greater than $5 \times 10^{3}$ cells, it was cell density and not cell number which affected the duration of interphase; below this value both factors appeared to be relevant.

Although cell density proved to be critical in the AF assay, it was not the only factor controlling $t_{\text {agg }}$. The same strain, harvested in the exponential phase of growth (see Gerisch et al., 1975a) may on different occasions display different rates of development. This was reflected in variations of several hours in the value of $t_{\text {ugg }}$ in separate experiments, but the response to the presence of $\mathrm{AF}$ was always marked.

\section{Partial purification of $A F$}

In the experiments described above we found that an acceleration factor is present in the suspension medium of aggregation-competent cells. This factor accelerated the development 


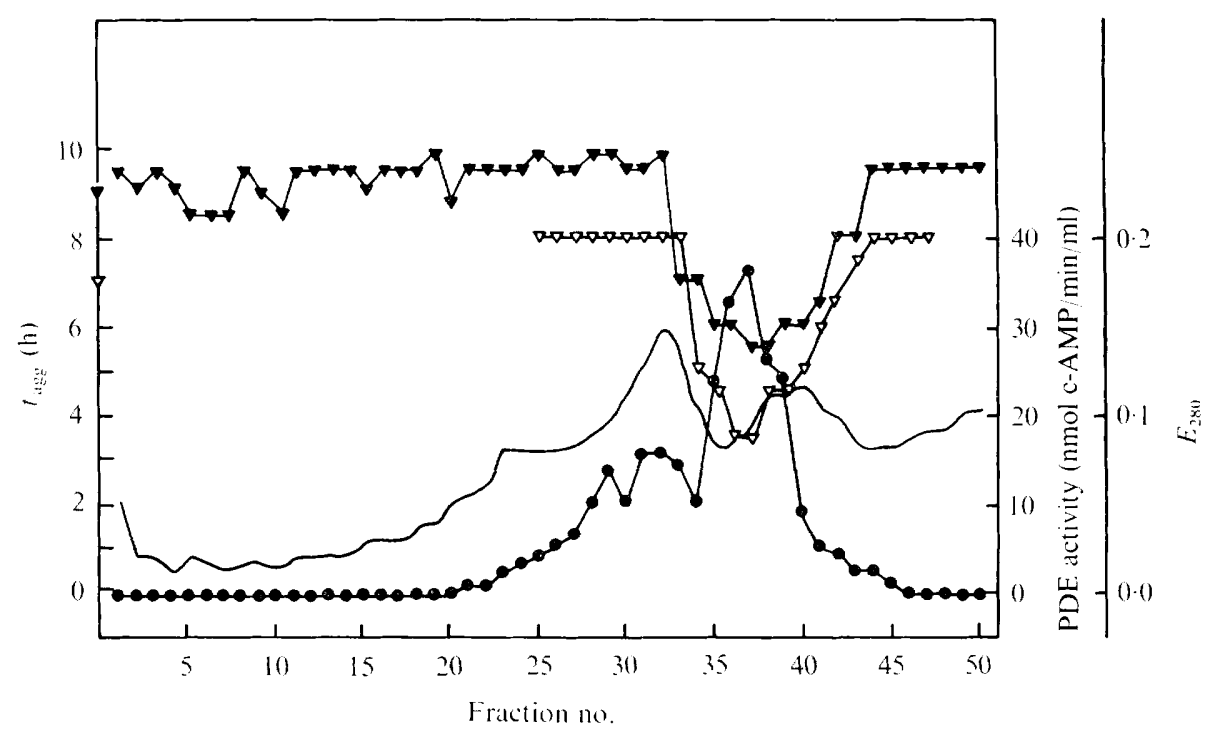

Fig. 2. DEAE cellulose chromatography of a $t_{10}$ supernatant. The column was eluted with a contimuous gradient of 0.0 to $0.4 \mathrm{M}-\mathrm{KCl}$ in $10 \mathrm{mM}-\mathrm{TEA}-\mathrm{HCl}, \mathrm{pH} \mathrm{6.8.} \mathrm{AF} \mathrm{activity,} \mathrm{expressed} \mathrm{as} t_{\mathrm{agg}}$, was measured in two experiments $(\nabla, \nabla)$; $\left(t_{\text {agg }}\right.$ values for the $\mathrm{KK} 2$ controls are shown on the ordinate);

0 , PDE activity; - - $E_{280}$. Deviation from the mean $t_{\mathrm{agg}} \leqslant 15 \mathrm{~min}$.

of aggregation competence when it was added at the beginning of the period of starvation. To investigate the nature of the factor(s) involved, we purified AF solutions by DEAE cellulose chromatography, gel filtration and electrophoresis. We always obtained a single peak of AF activity, the acceleration factor behaving as if it was identical with c-AMPphosphodiesterase or very closely associated with it.

Fractionation on DEAE cellulose. AF was purified from a six-times concentrated $t_{10} \mathrm{AF}$ solution by chromatography on DEAE cellulose. Figure 2 shows that AF activity and one peak of PDE activity co-fractionated when eluted with a gradient of 0.0 to $0.4 \mathrm{M}-\mathrm{KCl}$ in Io mM-TEA- $\mathrm{HCl}$ at $\mathrm{pH} \mathrm{6.8.} \mathrm{The} \mathrm{first} \mathrm{PDE} \mathrm{peak} \mathrm{(fractions} 22$ to 34), devoid of AF activity, was found to correspond to the high $K_{m}$ form of extracellular PDE; the second peak, coincident with AF activity, had a $K_{m}$ of approximately $10^{-6} \mathrm{M}-\mathrm{c}-\mathrm{AMP}$ (data not shown). The specific activity of extracellular PDE in fraction 37 was $360 \mathrm{u} / \mathrm{mg}$ protein, compared with $36 \mathrm{u} / \mathrm{mg}$ protein in the initial AF solution.

Fractionation on Sephadex G200. After DEAE cellulose chromatography, fractions 35 to 39 were combined and eluted from a Sephadex G200 column with 0.0I7 M-sodium-potassium phosphate $\mathrm{pH} 6 \cdot \mathrm{I}$. Figure 3 shows the elution profiles of AF and PDE activities with coinciding peaks between fractions 18 and 30 . PDE in fraction 23 had a specific activity of $776 \mathrm{u} / \mathrm{mg}$ protein. This represents a 2 -fold purification in relation to the enzyme in fraction 37 of DEAE cellulose chromatography (Fig. 2). The void volume for this column corresponded to the first $\mathrm{I} 8$ fractions $(22 \mathrm{ml})$. The end marker $\left(\mathrm{NaN}_{3}\right)$ was eluted at fraction 60 $(72 \mathrm{ml})$.

Disc gel electrophoresis. After electrophoresis of a 93-times concentrated AF solution on $7 \%$ polyacrylamide gels, $\mathrm{I} 6$ protein bands were revealed on staining with Coomassie blue. The migration distances ranged from 0.4 to $8.5 \mathrm{~cm}$ from the origin (bromophenol marker at $10.3 \mathrm{~cm}$ ). AF activity, coinciding with the larger peak in PDE activity (Fig. 4), was maximal 


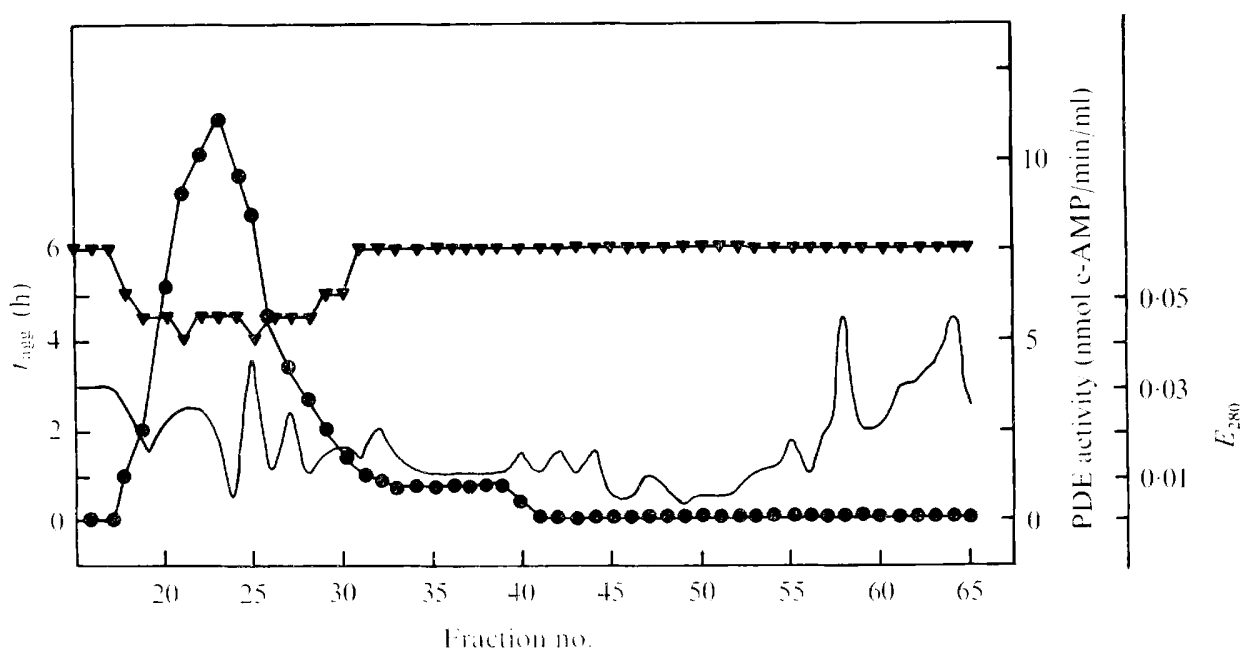

Fig. 3. AF and extracellular PDE purification on a Sephadex $\mathrm{G} 200$ column $(55 \times 1.5 \mathrm{~cm})$ after DEAE celullose chromatography. Fractions $(1.2 \mathrm{ml})$ were collected during elution with $0.017 \mathrm{M}$ sodium-potassium phosphate buffer, $\mathrm{pH} 6 \cdot 1$. Blue-dextran 2000 eluted in fraction 18 (void volume, $22 \mathrm{ml})$ and the end marker $\left(\mathrm{NaN}_{3}\right)$ in fraction $60(72 \mathrm{ml})$. ( $)$. AF activity, expressed as mean $t_{\text {agg }}$ for three replicas, I 5 min ( $t_{\text {agg }}$ for the $\mathrm{KK}_{2}$ control is indicated on the ordinate);, PDE activity; $\longrightarrow, E_{280}$. Deviation from the mean $t_{i t g y} \leqslant 15 \mathrm{~min}$.

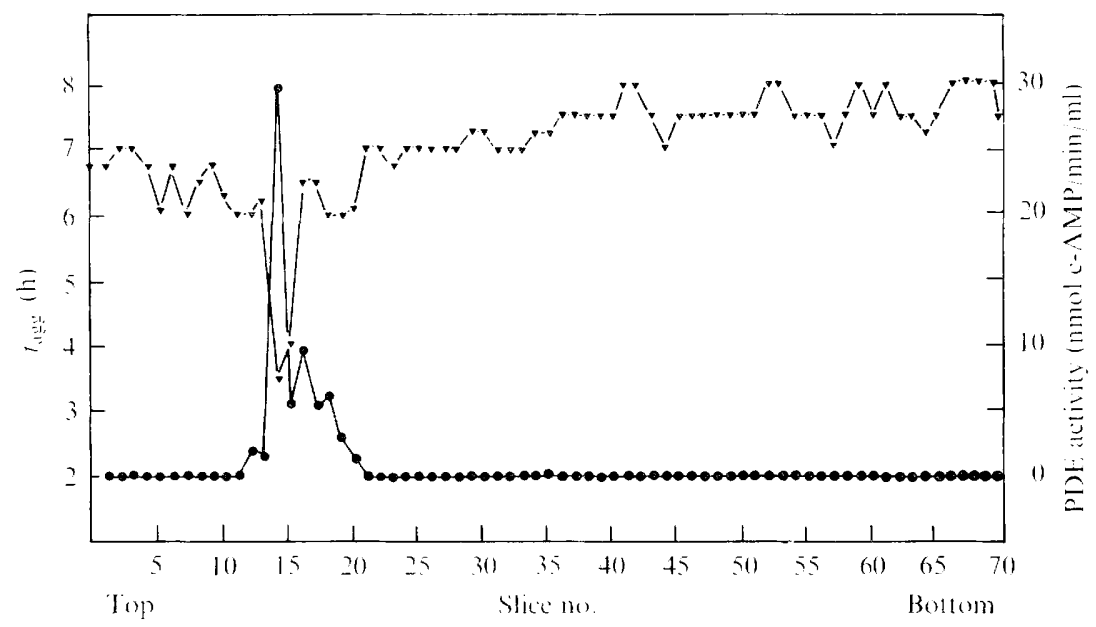

Fig. 4. Disc electrophoresis of AF solution (93 times concentrated $t_{10}$ supernatant) on $7 \%$ polyacrylamide gel. - PDE activity; $\boldsymbol{\nabla}, \mathrm{AF}$ activity, expressed as mean $t_{\text {agg }}$ for three replicas (the point on the ordinate represents $t_{\text {agg }}$ in the $\mathrm{KK}_{2}$ control). Deviation from the mean $t_{\mathrm{agg}} \leqslant 30 \mathrm{~min}$.

at $1.4 \mathrm{~cm}$ where no dense protein band was observed in stained replicas. PDE activity formed a second peak into a region of high protein content at $\mathrm{I} \cdot 7 \mathrm{~cm}$ from origin; probably this peak corresponded to the high $K_{m}$ form of extracellular PDE.

\section{$A F$ activity of rat-brain $P D E$}

On the basis of the evidence presented above we tested the hypothesis that PDE activity could account for AF activity, by using a completely distinct PDE with a $K_{m}$ value similar to that of $D$. discoideum PDE (approximately $\mathrm{IO}^{-6} \mathrm{M}-\mathrm{c}-\mathrm{AMP}$ ). 


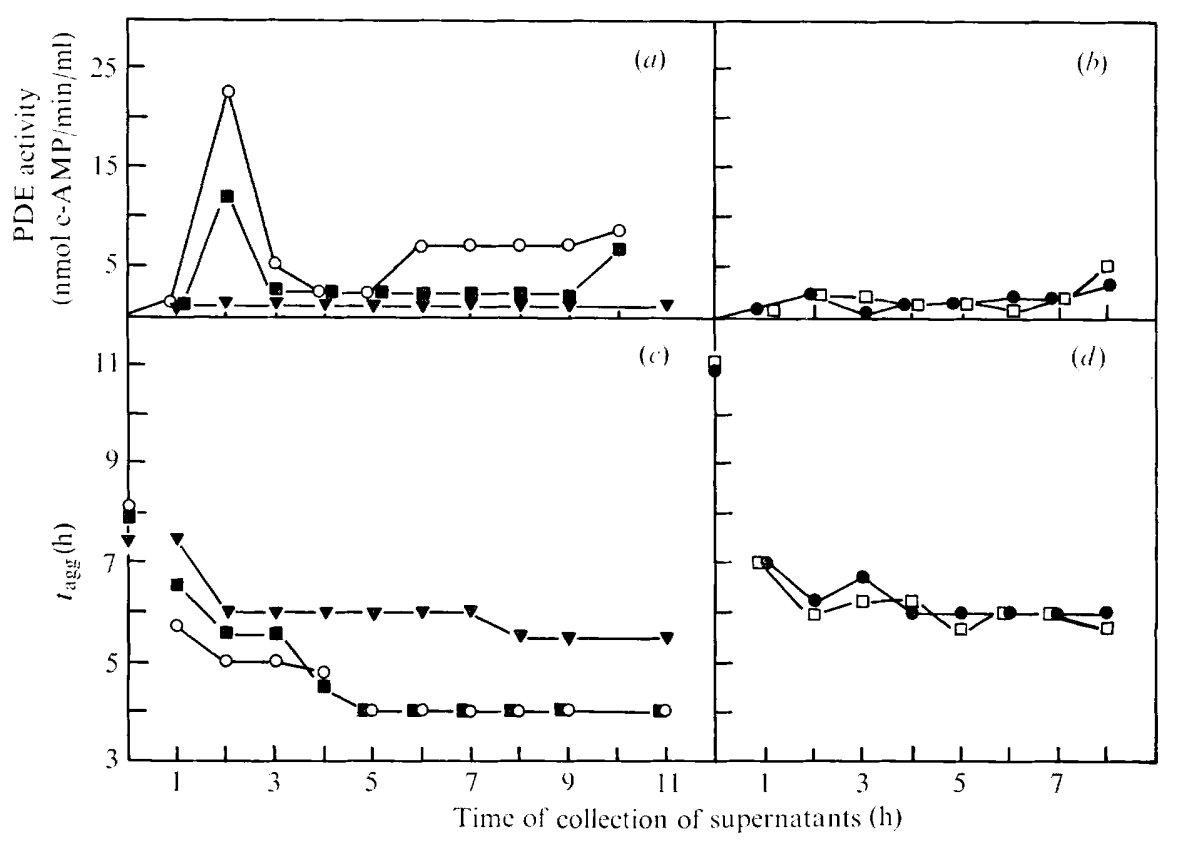

Fig. 5. AF and PDE activities in extracellular medium during interphase. Exponentially growing $\mathrm{Ax} 2$ cells were resuspended in $\mathrm{KK} 2$ buffer at (cells $/ \mathrm{ml}):(\mathrm{O}, \bigcirc) 8 \times 10^{7} ;(\square, \boldsymbol{\square}) 4 \times 10^{7} ;(\boldsymbol{\nabla})$ $3 \times 10^{6}$. The cells were either suspended by agitation $(a, c)$ or spread on NN agar plates $(b, d)$. Samples of extracellular medium were collected at various times after commencement of interphase, stored as AF solutions and assayed for PDE activity $(a, b)$ or AF activity expressed in terms of $t_{\text {agg }}(c, d)$. Each point in $(c)$ and $(d)$ represents the mean $t_{\mathrm{agg}}$ for five replicas; variation from the mean was $\leqslant 15 \mathrm{~min}$.

Table I. AF activity of rat-brain $P D E$

Assays were done on imidazole agar, with AX2 cells suspended in rat-brain PDE solutions or in control solutions (AX2 AF solution, KK2 buffer and imidazole buffer). The final PDE activity in each solution (units $/ \mathrm{ml}$ ) is given in parenthesis. Results are the means of five replicas; deviation from the mean did not exceed 15 min. Each line corresponds to a separate experiment.

\begin{tabular}{cccc}
\multicolumn{4}{c}{ Mean aggregation time, $t_{\text {agg }}(\mathrm{h})$} \\
\hline $\begin{array}{c}\text { Rat-brain PDE } \\
7(8)\end{array}$ & AX2 AF solution & KK2 buffer & Imidazole buffer \\
$5(50)-6(20)$ & $7(\mathrm{I} 2)$ & $9 \frac{1}{2}(0)$ & IO(o) \\
$6(4)-6(20)$ & $5(\mathrm{I} 8)$ & $8(0)$ & $8(0)$ \\
$6(4)-6(20)$ & $5(9)$ & $8(0)$ & $8(0)$ \\
& $6(9)$ & $8(0)$ & $8(0)$
\end{tabular}

Rat-brain PDE was prepared according to Thompson \& Appleman (197I). AF assays were carried out on imidazole agar both for test and control solutions, as rat-brain PDE activity appears to require $\mathrm{Ca}^{2+}$ and $\mathrm{Mg}^{2+}$ and is enhanced by imidazole (Cheung, I967; Lin, Liu \& Cheung, 1974).

Table I shows that rat-brain PDE stimulates acceleration of interphase to a degree comparable to AF from Ax2; this indicates that the AF effect depends only on c-AMP hydrolysis and that interactions of AX2 PDE with other molecules are not involved. 


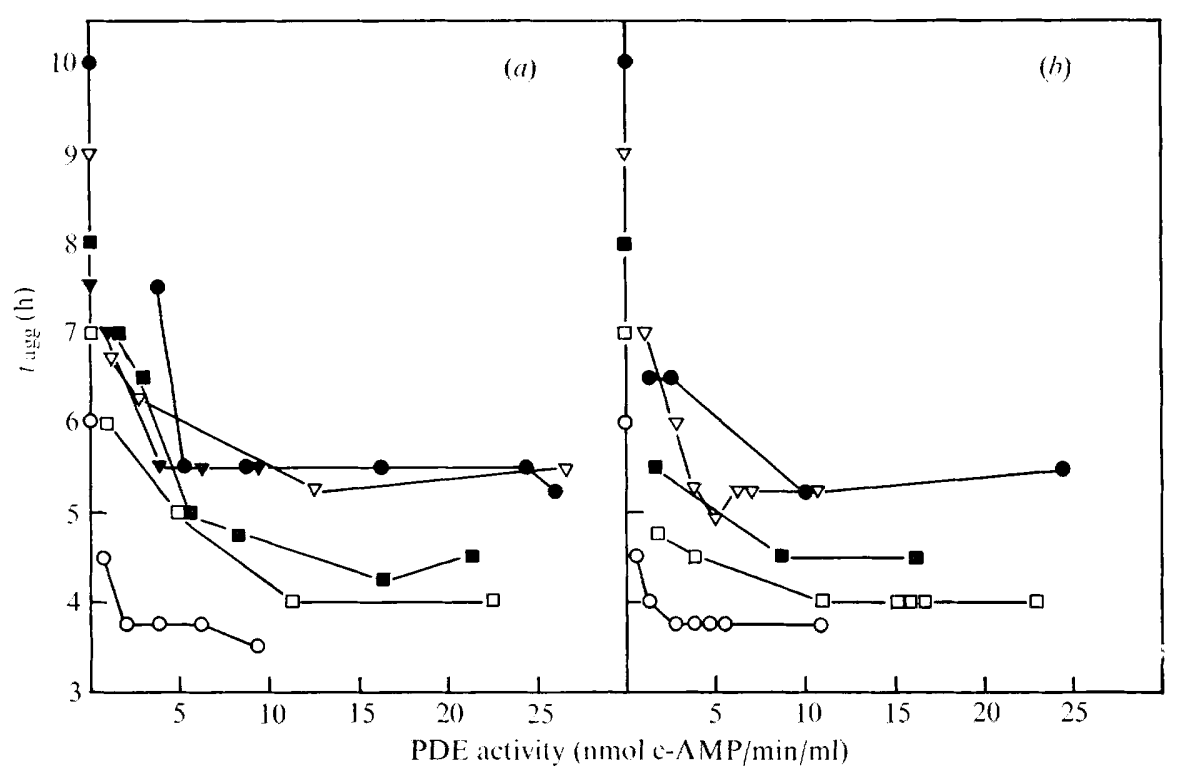

Fig. 6. Plots of $t_{\text {agg }}$ versus extracellular PDE activity. (a) Series of crude Ax $2 t_{2}$ supernatants at various diluticns (6 experiments); $(b)$ series of extracellular PDE, inhibited to various degrees. The supernatant was diluted in $\mathrm{KK}_{2}$ buffer; the ammonium sulphate preparation of a heated $t_{14}$ supernantant was used as the source of PDE inhibitor. In one experiment ( $\square$ ) the inhibitor solution was partially purified by DEAE cellulose chromatography. AF assays (expressed as $t_{\mathrm{agg}}$ ) were performed in parallel for each pair of series with the same symbols. Each point represents the mean $t_{\text {agg }}$ for each set of five replicas. Points on the ordinate represent the time of aggregation in the control (KK2 buffer). Maximum deviation from the mean $t_{\mathrm{agg}} \leqslant 15 \mathrm{~min}$.

\section{Time course of AF and extracellular PDE activity changes during interphase}

To investigate further the identity of AF and extracellular PDE, we followed the kinetics of changes in both activities in the extracellular medium of populations in the pre-aggregation stage. Populations of cells at different densities were kept in suspension in $\mathrm{KK}_{2}$ buffer with agitation at $\mathrm{I} 60 \mathrm{rev}$./min or were spread as a surface film on $\mathrm{NN}$-agar plates. The suspensions were sampled at intervals and a cell-free supernatant was collected and treated as described for preparation of AF solutions. At $4 \times 10^{7}$ and $8 \times 10^{7}$ cells $/ \mathrm{ml}$ extracellular PDE activity was maximal at $t_{2}$ (Fig. $5 a$ ) after which it decreased to about $2.5 \mathrm{u} / \mathrm{ml}$. The peak of activity at $t_{2}$ failed to appear in more sparse populations $\left(3 \times 10^{6} \mathrm{cells} / \mathrm{ml}\right)$ or when cells at the higher densities developed on agar surfaces (Fig. $5 a, b$ ). Although extracellular PDE formed a peak at $t_{2}$ in denser populations, AF activity could increase till $t_{5}$ (Fig. $5 c$ ). It appears that the later supernatant preparations with an extracellular PDE activity of about $2.5 \mathrm{u} / \mathrm{ml}$ are the most active in accelerating aggregation, while the apparent maximum level of extracellular PDE activity in earlier $\left(t_{2}\right)$ supernatants may not provide maximum AF activity.

\section{PDE activity versus AF activity}

Results presented above (Fig. 5) have shown that AF solutions with low levels of PDE activity were able to decrease $t_{\text {agg }}$ from $8 \mathrm{~h}$ (control) to $4 \mathrm{~h}$; solutions with less than $2.5 \mathrm{u}$ $\mathrm{PDE}$ activity/ml produced a less significant decrease. Within the error involved in the AF assay $( \pm 0.25 \mathrm{~h}$ ), data from six experiments (Fig. $6 a$ ) again show that $2.5 \mathrm{u} / \mathrm{ml}$ is the mean minimum value of PDE activity still compatible with maximum AF activity. Populations 
with extended interphases, as shown by $\mathrm{KK}_{2}$ controls, seemed to require higher PDE activities at $t_{0}$ (approximately $5 \mathrm{u} \mathrm{PDE} / \mathrm{ml}$ ).

\section{AF activity of inhibited $P D E$}

Figure 5(a) and (c) shows that although extracellular PDE activity reached its peak at $t_{2}$, when interphase took place in shaken suspensions, this peak did not coincide with maximum AF activity, which could occur 2 to $3 \mathrm{~h}$ later. At this time extracellular PDE activity had decreased significantly and it is known that this decrease results from the secretion into the medium of a natural inhibitor of extracellular PDE (Riedel \& Gerisch, 197I ; Riedel et al., 1972, I973). We therefore attempted to determine whether inhibited extracellular PDE still possesses AF activity. Inhibitor was prepared either by ammonium sulphate precipitation of a heated $t_{\mathbf{1 4}}$ supernatant or by partial purification of a fraction of the same supernatant on a DEAE cellulose column. The two methods did not produce significantly different results. The $t_{2}$ supernatants, at a constant final dilution, were used as PDE source and the degree of PDE inhibition was varied by the addition of a range of concentrations of inhibitor.

Partial inhibition of extracellular PDE to an activity below $2.5 \mathrm{u} / \mathrm{ml}$ decreased AF activity (Fig. $6 \mathrm{~b}$ ). Again, a PDE activity of $2.5 \mathrm{u} / \mathrm{ml}$ appears to be the lowest limit consentaneous with maximum AF activity. When extracellular PDE activity was added to solutions of partially-inactivated extracellular PDE, high levels of both AF and PDE activities were restored, in contrast to controls where $\mathrm{KK}_{2}$ buffer was substituted for the extra PDE solution. Loss of AF activity is therefore due to loss of PDE activity and not to a toxic effect of the PDE-inhibitor. The PDE-inhibitor solution alone, added at $t_{0}$ allows for a $t_{\text {agg }}$ similar or slightly increased (by $\mathrm{I}$ to $2 \mathrm{~h}$ ) in relation to the control. We conclude that inhibited extracellular PDE is not active as AF and that $2.5 \mathrm{u} \mathrm{PDE} / \mathrm{ml}$ is, approximately, the threshold at which maximum AF activity results. We do not know why Ax2 $t_{2}$ supernatants of agitated cell suspensions never showed AF activity as high as late supernatants; possibly $t_{2}$ supernatants contain a product which is slightly inhibitory for differentiation, or contain a higher proportion of high- $K_{m}$ PDE than supernatants taken at later times.

\section{AF activity of insolubilized $A F$}

To investigate if AF activity was limited to the extracellular medium, as the results with rat-brain PDE seemed to indicate, we prevented its uptake by the cells or its incorporation at the cell surface by covalently binding AF to Sepharose beads. Insoluble AF was obtained from three separate preparations: crude $t_{14}$ supernatant; crude $t_{2}$ supernatant; $t_{14}$ supernatant purified by DEAE cellulose chromatography. Recovery of PDE activity after coupling to $\mathrm{CNBr}$-activated Sepharose $-4 \mathrm{~B}$ varied between $\mathrm{I} \cdot 5$ and $3.6 \%$. The final PDE activities in the different gel suspensions are indicated in Table 2. For AF assays, Io $\mu 1$ of gel suspension were placed on $\mathrm{NN}$-agar plates and the excess liquid was sucked off before deposition of $10 \mu$ of a cell suspension in $\mathrm{KK}_{2}$ buffer on to the sedimented beads. Results in Table 2 show that in Expt A, where a high density of beads was used, the AF activity in soluble and insoluble AF was identical. In Expts B and C the gel suspensions were diluted by a factor of 2 to circumvent the difficulty in microscopic observation; $t_{\mathrm{agg}}$ in these preparations, although increased in relation to the soluble forms of AF, was still markedly less than the value for the KK2 control. Supernatants derived from AF gels and a control gel (inactivated Sepharose-4B) failed to produce any acceleration of interphase. It appears likely, therefore, that AF activity of PDE is due to c-AMP hydrolysis in the extracellular medium. 
Table 2. AF activity of insolubilized AF compared with activity

in the corresponding soluble forms

PDE activity (units/ml) is given in parentheses. Data from three experiments are presented. In expt (A), a high density of beads was used; in expts (B) and $(C)$ the gel suspensions were diluted 2 -fold in $\mathrm{KK} 2$ buffer, to facilitate microscopic observation. The supernatants of AF gels and a control gel (inactivated-Sepharose-4B) produced $t_{\text {ags }}$ values similar to $t_{\mathrm{agg}}$ in the $\mathrm{KK} 2$ control.

\begin{tabular}{|c|c|c|c|}
\hline & \multicolumn{3}{|c|}{$t_{\mathrm{ag},}(\mathrm{h})$} \\
\hline & (A) & (B) & (C) \\
\hline Insoluble $t_{14}$ & $6(2.5)$ & $5 \frac{1}{2}(\mathrm{I} \cdot 25)$ & $6(\mathrm{I} \cdot 25)$ \\
\hline Soluble $t_{14}$ & $5 \frac{1}{2}(16)$ & $3 \frac{1}{2}(16)$ & $4(16)$ \\
\hline Insoluble $t_{2}$ & $5 \frac{1}{2}(4)$ & $5 \frac{1}{2}(2)$ & $6(2)$ \\
\hline Soluble $t_{2}$ & $6(64)$ & $4(64)$ & $4 \frac{1}{2}(64)$ \\
\hline Insoluble $\mathrm{F} t_{1:}$ & $6 \frac{1}{2}(2 \cdot 5)$ & $5(\mathrm{I} \cdot 25)$ & $5 \frac{1}{2}(1 \cdot 25$ \\
\hline Soluble $F t_{14}{ }^{*}$ & $6(20)$ & $4(20)$ & $4 \frac{1}{2}(20)$ \\
\hline KK2 buffer & $8 \frac{1}{2}(0)$ & $7 \frac{1}{2}(0)$ & $9 \frac{1}{2}(0)$ \\
\hline
\end{tabular}

* AF in DEAF-fractionated $t_{14}$ supernatant.

\section{Effect of $c-A M P, 5^{\prime}-A M P, A$ and adenine on duration of interphase}

Addition of 5 -AMP, adenosine or adenine, at $1 \mu \mathrm{M}$ or $0.5 \mathrm{~mm}$, to the $\mathrm{KK} 2$ buffer used as suspending media in AF assays did not cause acceleration or retardation of interphase in comparison to the KK2 control. c-AMP ( $/ \mu \mathrm{M}$ ) was equally ineffective but $0.5 \mathrm{mM}$-c-AMP caused a small delay in the onset of aggregation. In conditions where the AF solution promoted aggregation competence in $3.5 \mathrm{~h}$, addition of $0.5 \mathrm{~mm}-\mathrm{c}-\mathrm{AMP}$ to AF increased $t_{\mathrm{agg}}$ to $5.5 \mathrm{~h}\left(t_{\text {agg }}\right.$ in the $\mathrm{KK} 2$ control $=8 \mathrm{~h}$ ). Adenine, adenosine and $5^{\prime}$-AMP at $0.5 \mathrm{~mm}$ in AF solution did not affect $t_{\text {agg }}$ as compared to the AF control. These results support the conclusion that AF activity depends on the hydrolysis of extracellular c-AMP but not on the products of this hydrolysis.

\section{Chemotaxis and stream formation in AF-treated cells}

We wanted to know whether AF (as PDE) accelerated the onset of aggregation by facilitating signalling after the aggregation competence stage, or whether it actually increased the rate of differentiation toward this stage. If the effect was only to facilitate signalling, then chemotaxis toward artificial sources of $\mathrm{C}-\mathrm{AMP}$, which does not require cell signalling, might develop in AF-treated populations at the same time as in the control (KK2-treated) populations. On the other hand, if differentiation was accelerated, both chemotaxis and streaming (which includes increase in c-AMP receptors, capacity for signal amplification and formation of EDTA-resistant cell contacts) would develop earlier in AF-treated cells than in controls.

At the beginning of interphase, cells at $7 \times 10^{16} / \mathrm{ml}$ were resuspended in AF solution or $\mathrm{KK} 2$ buffer and several Io $\mu 1$ samples were deposited on $\mathrm{NN}$-agar plates. At hourly intervals during interphase, two samples of each population were challenged with $5 \mu \mathrm{l}$ of a $O^{-1} \mathrm{mM}-\mathrm{c}-$ AMP solution placed at about $\mathrm{I} \mathrm{mm}$ from the periphery of each population. The times of positive chemotactic response as separate cells (detected as a common orientation in cell elongation within the c-AMP source range) and of stream formation towards the artificial source of attractant were determined by microscopic observation (Table 3); KK2 controls, to measure spontaneous aggregation, were not challenged with c-AMP but otherwise conditions were the same. Chemotaxis was never evident in the controls before $t_{8}$ but AF- 
Table 3. Response to an artificial source of $c$-AMP by AF- and KK2 buffer-treated cells

At $t_{0}$ several $10 \mu \mathrm{l}$ samples of suspensions at $7 \times 10^{6}$ cells $/ \mathrm{ml}$ of $\mathrm{KK} 2$ buffer or AF solution were deposited on NN-agar plates and incubated. Samples were tested hourly for response toward sources of c-AMP ( $10^{-4} \mathrm{M}$ solution) placed approximately $1 \mathrm{~mm}$ from their periphery. Time of chemotactic response as separate cells and with formation of streams is indicated, as well as $t_{\text {agg }}$ in non-challenged populations. In expts $(A)$ and $(B)$, cells were suspended in two times concentrated $t_{14}$ supernatant (44 units/ml PDE); in expt (C), cells were suspended in $t_{2}$ supernatant (20 units $/ \mathrm{ml}$ PDE).

$\begin{array}{ccccr}\begin{array}{c}\text { Expt } \\ \text { no. }\end{array} & \begin{array}{c}\text { Extracellular } \\ \text { medium }\end{array} & \begin{array}{c}\text { Separate cells } \\ \text { (h) }\end{array} & \begin{array}{c}\text { Streams } \\ \text { (h) }\end{array} & \begin{array}{r}\text { Spontan } \\ \text { aggrega } \\ t_{\text {agg }}\end{array} \\ \text { A } & & 4 & 5 \frac{1}{2} & 6 \\ & \mathrm{AF} & 8 & 8-9 & 10 \\ \mathrm{BK} 2 & 4-5 & 5-6 & 6 \\ & \mathrm{AF} & 8-9 & 8-10 & 10 \frac{1}{2} \\ \mathrm{C} & \mathrm{KK2} & 3 \frac{1}{2}-5 & 5 \frac{1}{2} & 5 \frac{1}{2} \\ & \mathrm{AF} & 8-9 & 9 & 9 \frac{1}{2}\end{array}$

treated cells showed a clear response from about $t_{4}$ or $t_{5}$. The time when ability to form streams developed was always very ciose to the time of spontaneous aggregation $\left(t_{\text {agg }}\right)$, though this differed in AF and control populations by 3.5 to $4 \mathrm{~h}$. Results for $10 \mu \mathrm{M}-\mathrm{c}-\mathrm{AMP}$ solutions were similar, except that the influence of c-AMP had a smaller range. These results support the hypothesis that AF accelerates the rate of differentiation toward aggregation competence.

\section{Period of action of $A F$}

The results so far indicate that at some stage of interphase extracellular c-AMP inhibits development, but that the addition of extra PDE at this stage overcomes this barrier. It was important to delineate this period. We therefore investigated the effects of the addition and removal of $\mathrm{AF}$ at various times during interphase.

Ax2 cells suspended in AF solutions or $\mathrm{KK}_{2}$ buffer at the initiation of interphase were either kept in suspension with agitation (Fig. $7 a, b)$ or were spread as a film on the surface of $\mathrm{NN}$-agar plates (Fig. $7 c, d$ ). Each cell preparation was sampled several times during interphase by taking $100 \mu \mathrm{l}$ volumes directly from the suspension or from the agar preparations. The latter was done after gentle detachment of the cells by re-spreading with a glass rod; distinct cell preparations were used each time to avoid repeated re-spreading. After centrifuging at $260 \mathrm{~g}$ for I min, cells from each sample were resuspended at the initial density $\left(5 \times 10^{6}\right.$ to $7 \times 10^{6}$ cells $\left./ \mathrm{ml}\right)$ either in $\mathrm{KK} 2$ buffer or in freshly-thawed AF solution. At each time (see Fig. 7) four cell suspensions were obtained: AF pretreated cells resuspended in AF solution (control); AF pretreated cells resuspended in $\mathrm{KK}_{2}$ buffer (to determine the effect of difference in time of removal of $\mathrm{AF}$ ); $\mathrm{KK}_{2}$ pretreated cells resuspended in $\mathrm{KK} 2$ (control); and $\mathrm{KK}_{2}$ pretreated cells resuspended in AF solution (to determine the effect of difference in the time of addition of AF). Ten $\mu$ l samples (five replicas) of each cell suspension were deposited on $\mathrm{NN}$ agar and $t_{\mathrm{agg}}$ was monitored by microscopic observation. At this cell density, the conditions of incubation during pretreatment (shaken suspensions or preparations on agar) did not appear to have any marked effect on the overall results. AF activity, measured as $t_{\text {agg }}$ in relation to the $\mathrm{KK} 2$ control, was decreased (though to a progressively smaller extent) by a delay in the addition of AF, up or close to the stage of aggregation competence. This indicates that, besides its function in early interphase, AF may continue to 


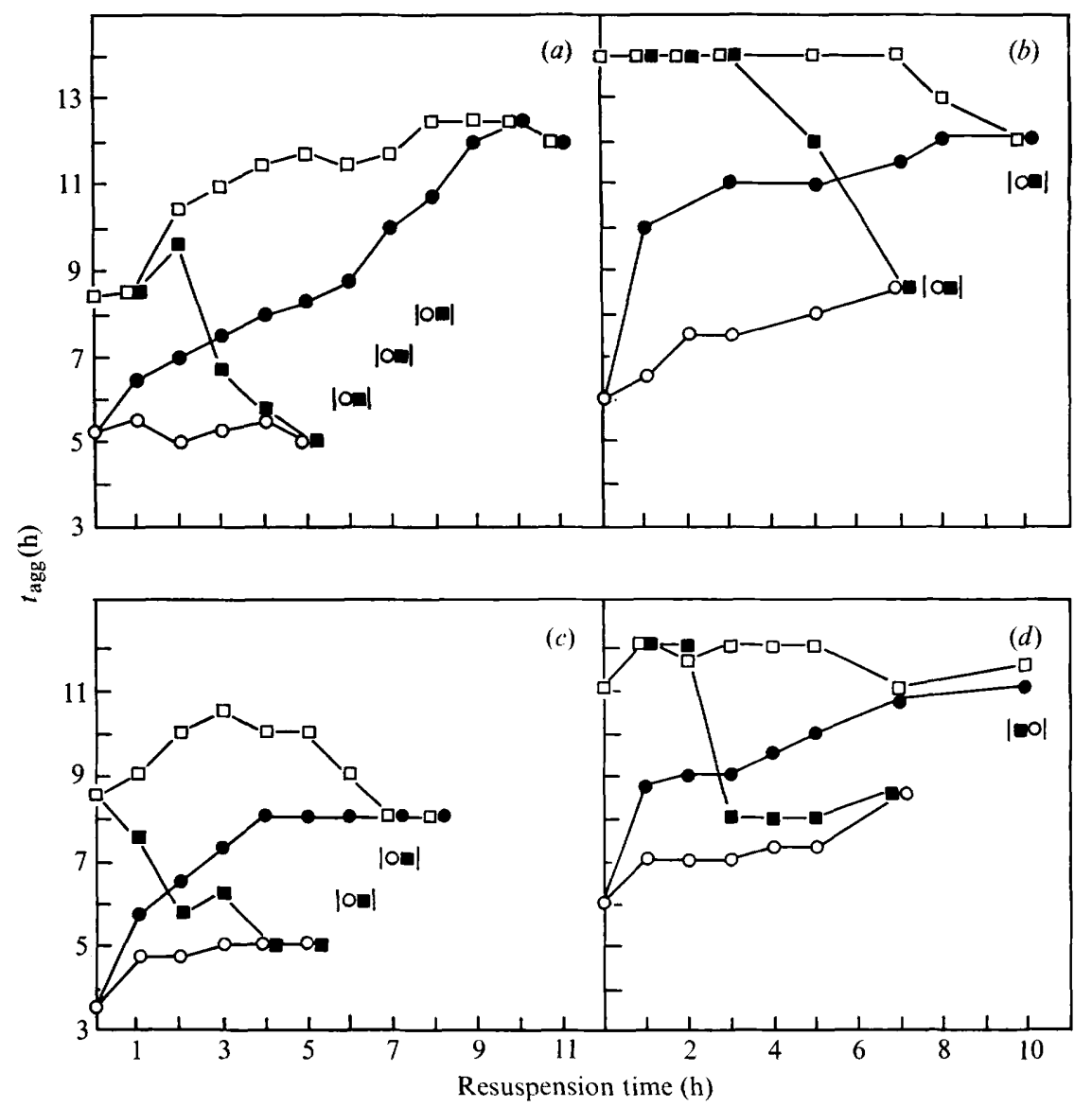

Fig. 7. Period of action of AF. Four experiments were conducted in which Ax2 cells, suspended at $t_{0}$ in $\mathrm{KK} 2$ buffer and AF solutions, were either kept in suspension by agitation $(a, b)$ or spread on $\mathrm{NN}$-agar plates $(c, d)$. After interphase had continued for various times, samples were taken from the initial cell suspensions, and either $(\boldsymbol{\sigma})$ the AF solution was replaced by KK2 buffer, or $(\boldsymbol{O})$ $\mathrm{KK} 2$ buffer was replaced by AF solution. Controls were under the same conditions except that cells were resuspended in the same type of medium as used for pretreatment: (O), AF-pretreated cells resuspended in AF; $\square, \mathrm{KK} 2$ buffer-pretreated cells resuspended in $\mathrm{KK} 2$, buffer. Time of aggregation $\left(t_{\mathrm{agg}}\right)$ was monitored microscopically on $\mathrm{I} O \mu \mathrm{l}$ populations deposited on NN agar when resuspended. Each point represents the mean $t_{\text {igg }}$ for each set of five replicas; deviation from the mean $\leqslant$ I 5 min. Points enclosed in bars denote immediate re-aggregation. PDE activity in the AF solutions: $(a, b)$ Io units $/ \mathrm{ml} ;(c) 20$ units $/ \mathrm{ml} ;(d) 13$ units $/ \mathrm{ml}$.

act until late in the pre-aggregation stage. The effect of the presence of AF during the first hour of development was marked. Removal of AF at different times of interphase in three of the experiments indicated that, although active since $t_{0}$, the effects of $\mathrm{AF}$ during the first hours of interphase were reversible. AF (extracellular PDE) became completely dispensable when cells reached the stage of aggregation competence, as shown by the immediate reaggregation of competent cells suspended in AF or KK2 solutions (Fig. 7, points enclosed in bars). 


\section{DISCUSSION}

Preliminary experiments showed that the AF was thermo-labile and was retained by ultrafiltration membranes with a nominal cut-off at rooo daltons, which indicated that AF was probably not a small molecule such as a nucleotide. Present evidence suggests that it is a protein. It is precipitated by ammonium sulphate. On DEAE cellulose and gel filtration columns, fractions exhibiting AF activity also exhibited a proportionate PDE activity. Electrophoresis on polyacrylamide gels also revealed that the two activities coincided. The inference that PDE activity is necessary for AF to affect development is supported by the evidence that a specific inhibitor of extracellular PDE can diminish the effect of the AF (Fig. 6). Extracellular PDE may have a role during growth (Malchow, Fuchila \& Nanjundiah, 1975), and during aggregation it may reduce the signal to noise ratio (Shaffer, 1956; Chassy, Love \& Krichevsky, I969; Goidl et al., 1972) and steepen c-AMP gradients (Bonner et al., 1969; Chassy, 1972; Gerisch et al., 1972). The extracellular inhibitor of extracellular PDE has been studied by Gerisch and his collaborators (Riedel \& Gerisch, 1971; Gerisch et al., 1972; Riedel et al., 1972, 1973). Its role is unknown, but it was suggested that inhibition of extracellular PDE may be necessary during later interphase so that the c-AMP concentration can rise to a level which maintains the shift from vegetative to developing state (Chassy et al., 1972; Bonner, 1970; Riedel \& Gerisch, 1971 ; Gerisch et al., 1972). The limited data available might lead one to expect that extracellular PDE plays an active part in aggregation but not in interphase. We found, on the contrary, that it made little difference whether extracellular PDE was present during aggregation but that this did have a marked effect on the duration of interphase (Fig. 7). We are thus left without any role to ascribe to the slime-mould extracellular-PDE inhibitor.

The close association of AF and PDE activity throughout various fractionation procedures indicated that PDE alone, or PDE complexed with other proteins, might be responsible for the effects of AF. We therefore attempted to determine whether these effects were due solely to PDE activity or whether some function in addition to the hydrolysis of c-AMP is involved. For example, PDE might have a dual role, as an enzyme and as a participant in the formation or stabilization of cell contacts. The experiments with rat-brain PDE were carried out with the aim of testing this possibility. It is unlikely that rat-brain enzyme can form specific complexes with $D$. discoideum proteins as postulated for a 'dual role' slime-mould PDE. The only significant property the two enzymes are likely to have in common is the capacity to hydrolyse c-AMP. Therefore the ability of rat-brain PDE to reproduce the effects of slime-mould PDE on development during interphase is evidence that these effects depend only on the extracellular c-AMP concentration and not on any other factor, i.e. a dual role for slime-mould extracellular PDE seems to be excluded.

Evidence for the exclusively extracellular activity of AF is also provided by the experiments with Sepharose-bound slime-mould PDE, which, after binding, kept both activities.

Consistent with this interpretation of the effects of PDE in our experiments, we also found that c-AMP (but not 5'-AMP, A or adenine) was able to decrease the apparent AF activity when added at $t_{0}$ at a concentration of $0.5 \mathrm{~mm}$. Moreover, none of the tested products of c-AMP hydrolysis (5'-AMP, A or adenine) at concentrations of I $\mu \mathrm{M}$ or $0.5 \mathrm{~mm}$ had any effect on the duration of interphase. This suggests that $t_{\text {agg }}$ is dependent on the extracellular c-AMP concentration.

To distinguish between possible early or late effects of PDE on the development of aggregation competence we followed the expression of the ability to respond chemotactically to an artificial source of c-AMP (Table 3). Increased chemotactic ability develops before 
aggregation competence (Bonner et al., 1969), so if extracellular PDE acted only during the process of aggregation itself, or at a stage immediately preceding it, then the development of chemotactic ability should be unaffected by PDE pretreatment. Alternatively, if extracellular PDE acted early in interphase, then chemotaxis, as well as aggregation competence, might be expressed earlier in PDE-treated cells than in controls. We found that the development of chemotaxis was accelerated by extracellular PDE. This, and the results of experiments in which cells were treated at various times throughout interphase with extracellular PDE (Fig. 7), suggest an early action of extracellular PDE (AF). It seems that there is a period $\left(t_{0}\right.$ to $\left.t_{2}\right)$ during which there is high sensitivity to AF and its effects are reversible; at a later stage ( $t_{2}$ to $t_{\text {igg }}$ ) the cells are less sensitive to AF and its effects are largely irreversible (Fig. 7).

The variation of $t_{\mathrm{agg}}$ with cell density might also be explained on the basis of PDE activity: we suggest that extracellular PDE (AF) becomes dispensible when the membrane-bound PDE activity reaches a threshold value at some time before aggregation. In dense populations, the combined activity of extracellular and membrane-bound phosphodiesterases reaches the threshold value early in interphase and so development is accelerated. In sparse populations, the extracellular c-AMP concentration is probably controlled locally by membrane-bound PDE, as extracellular PDE activity in the medium must be negligible.

The experiments with rat-brain PDE, slime-mould PDE immobilized on Sepharose and with inhibited slime-mould PDE all indicate that extracellular c-AMP concentration is a major factor in determining the duration of interphase. Possible explanations are: (i) low c-AMP is a developmental trigger which starts a chain of biochemical changes; (ii) low extracellular c-AMP accelerates development but by a continuous rather than a triggering mechanism; (iii) high c-AMP concentrations inhibit development and low c-AMP concentrations do not accelerate it. Hypothesis (i) may be discarded as cells briefly exposed to PDE in early interphase aggregated later than cells exposed continuously; also, washing and resuspending cells in buffer (the usual procedure used to start development in a population) provides initial conditions with low c-AMP concentration which, on this hypothesis, should be as effective as the addition of PDE. We conclude that the acceleration of the development of aggregation competence by extracellular PDE is probably a continuous process in which development takes place more quickly when c-AMP concentrations are kept low; however, our experiments do not distinguish between complementary models in which either high c-AMP concentration inhibits development or low c-AMP accelerates it.

Gerisch \& Hess (1974) and Roos et al. (1975) showed that spontaneous oscillations of extracellular c-AMP may be induced or synchronized at early stages of interphase $\left(t_{3}\right)$ with artificial pulses of c-AMP. Gerisch et al. (1975a) observed that expression of membranebound PDE, c-AMP receptor sites and contact sites A was accelerated by artificial pulses of c-AMP. Also Darmon et al. (1975) found that aggregation competence developed in Ax2 cells in $4 \mathrm{~h}$ when they were continuously signalled with c-AMP pulses of $10^{-6}$ to $10^{-8} \mathrm{M}$ for $3 \mathrm{~h}$; this compares with a $t_{\mathrm{agg}}$ of $6 \mathrm{~h}$ in controls. Thus, there is strong evidence that oscillations in c-AMP synthesis, released or etection, control the rate of development. It is also known (Gerisch \& Hess, 1974) that a constant flow of 3 to $50 \mathrm{nmol}$ c-AMP/min/l suppresses pre-established oscillations in c-AMP secretion and probably also supresses oscillations in intracellular c-AMP concentration. It seems that acceleration of development of aggregation competence could never be related to steady concentrations of c-AMP.

The mechanism of induction and suppression of c-AMP oscillations is not known. Since oscillations occur synchronously throughout the population (Gerisch \& Hess, 1974), it seems that c-AMP receptors must somehow be involved. These receptors may be an integral part of the control loop generating c-AMP oscillations; alternatively, binding of 
c-AMP to receptors may be translated into other signals which then affect the control loop (Gerisch et al., 1975b). In either case there is clearly a possibility that c-AMP oscillations can be suppressed if c-AMP receptors are saturated by extracellular c-AMP. We think that the effects of PDE we have observed can be explained in this way. By hydrolysing extracellular c-AMP, PDE clears receptor sites and lowers the level of background noise against which c-AMP pulses must be detected. This allows c-AMP pulses to be detected early in interphase at times when the signals are probably too weak, and the efficiency of detection too low, to produce a response.

We found that PDE had a particularly marked effect on development during the first hour of interphase. Presumably, at this time suppression of c-AMP oscillations by extracellular c-AMP is maximal; this is reasonable, since one might expect that in the first hour c-AMP receptors are few (so efficiency of signal detection is poor) and endogenous PDE is low (so a high 'noise' level of extracellular c-AMP can accumulate) and it is known that c-AMP is secreted in early interphase (Malkinson \& Ashworth, I973).

It appears (Fig. 7) that development is affected by extracellular PDE from the beginning of interphase. This implies that the c-AMP oscillator is already able to function at $t_{0}$ and is therefore not dependent on the development occurring during interphase, in contrast to the observation of Darmon et al. (1975) that the first hour of artificial c-AMP signalling was ineffective in accelerating development. Possibly the lag, in their experiments, corresponded to a period when PDE activity was still too low to remove background noise efficiently; after this period, artificial signalling with c-AMP pulses $\left(\mathrm{IO}^{-6}\right.$ to $\left.1 \mathrm{I}^{-8} \mathrm{M}\right)$ promoted an increased rate of differentiation. We interpret these results as indicating that the background noise at and after $t_{1}$ is smaller than $10^{-8} \mathrm{M}-\mathrm{c}$-AMP and that natural signals have a smaller amplitude or frequency than the artificial signals.

The relationship between c-AMP oscillations and development in $D$. discoideum is currently a matter of great interest. Our study prompts us to ask how closely coupled these processes are: whether c-AMP oscillations are indispensible for development to aggregation competence, or whether they simply control the rate at which development progresses.

We thank Dr Marilyn Monk, Dr J. Gross and Dr J. Collins for helpful discussions and suggestions.

\section{REFERENCES}

AlcÂntara, F. \& Monk, M. (1974). Signal propagation in the cellular slime mould Dictyostelium discoideum. Journal of General Microbiology 85, 32I-324.

Ashworth, J. M. (197I). Cell development in the cellular slime mould Dictyostelium discoideum. Symposia of the Society for Experimental Biology 25, pp. 27-49.

BARKLEY, D. S. (1969). Adenosine-3'-5'-phosphate: identification as acrasin in a species of cellular slime mold. Science, New York 165, I I 33-I134.

Beug, H., Katz, F. E. \& Gerisch, G. (1973a). Dynamics of antigen membrane sites relating to cell aggregation in Dictyostelium discoideum. Journal of Cell Biology 56, 647-658.

Beug, H., Katz, F. E., Stein, A. \& Gerisch, G. (I973b). Quantitation of membrane sites in aggregating Dictyostelium cells by use of tritiated univalent antibody. Proceedings of the National Academy of Sciences of the United States of America 70, 31 50-31 54.

BONNER, J. T. (1970). Induction of stalk cell differentiation by cyclic AMP in the cellular slime mold Dictyostelium discoideum. Proceedings of the National Academy of Sciences of the United States of America $\mathbf{6}_{5}$, I I O-I I 3 .

Bonner, J. T., Barkley, D. S., Hall, E. M., Konijn, T. M., Mason, J. W., O'Keefe, G. \& Wolfe, P. B. (1969). Acrasin, acrasinase, and the sensitivity to acrasin in Dictyostelium discoideum. Developmental Biology 20, 72-87.

Bonner, J. T., Kelso, A. P. \& Gillmor, R. G. (I966). A new approach to the problem of aggregation in the cellular slime molds. Biological Bulletin r3o, 28-42. 
CHASsy, B. M. (1972). Cyclic nucleotide phosphodiesterase in Dictyostelium discoideum: interconversion of two enzyme systems. Science, New York 175, 1016-1018.

Chassy, B. M., Love, L. L. \& Krichevsky, M. 1. (1969). The acrasin activity of $3^{\prime}-5^{\prime}$-cyclic nucleotides. Proceedings of the National Academy of Sciences of the United States of America 64, 296-303.

Cheung, W. Y. (1967). Properties of cyclic 3'-5'-nucleotide phosphodiesterase from rat brain. Biochemistry 6, $1079-1087$.

Davis, B. J. (I064). Disc electrophoresis. II. Method and application to human serum proteins. Annals of the New York Academy of Sciences I2I, 404-427.

Darmon, M., Brachet, P. \& Pereira da Silva, L. H. (1975). Chemotactic signals induce cell differentiation in Dictyostelieum discoideum. Proceedings of the National Academy of Sciences of the United States of America 72, 3163-3166.

Gerisch, G. (1965). Stadienspezifische Aggregationsmuster bei Dictyostelium discoideum. Roux Archiv für Entwicklungsmechanik der Organismen 156, I 27-1 44.

GERISCH, G. (I 968). Cell aggregation and differentiation in Dictyostelium. In Current topics in Developmental Biology, vol. 3, pp. I57-197. Edited by A. A. Moscona and A. Monroy. New York and London: Academic Press.

Gerisch, G., Fromm, H., Huesgen, A. \& Wick, U. (1975a). Control of cell-contact sites by cyclic-AMP pulses in differentiating Dictyostelium cells. Nature, London 255, 547-549.

Gerisch, G. \& Hess, B. (I974). Cyclic-AMP-controlled oscillations in suspended Dictyostelium cells: their relation to morphogenetic cell interactions. Proceedings of the National Academy of Sciences of the United States of America 7r, 2118-21 22.

Gerisch, G., Hülsen, D., Malchow, D. \& Wick, U. ( $975 b$ ). Cell communication by periodic cyclic-AMP pulses. Philosophical Transactions of the Royal Society $\mathbf{B}$ 272, I $8 \mathrm{I}-192$.

Gerisch, G. \& MalChOW, D. ( I974). Cell communication and cyclic-AMP regulation during aggregation of the slime mold Dictyostelium discoideum. In Biochemistry of Sensory Functions, pp. 279-298. Edited by L. Jaenicke. Berlin, Heidelberg and New York: Springer-Verlag.

Gerisch, G., Malchow, D., Riedel, V., Müller, E. \& Every, M. (1972). Cyclic AMP phosphodiesterase and its inhibitor in slime mould development. Nature New Biology 235, 90-92.

Goidl, E. A., Chassy, B. M., Love, L. L. \& Krichevsky, M. I. (1972). Inhibition of aggregation and differentiation of Dictyostelium discoideum by antibodies against adenosine $3^{\prime}-5^{\prime}$-cyclic monophosphate diesterase. Proceedings of the National Academy of Sciences of the United States of America 69, I $128-1$ I 30.

KoniJn, T. M. (1968). Chemotaxis in the cellular slime moulds. II. The effect of cell density. Biological Bulletin 134, 298-304.

KoniJn, T. M. \& RAPER, K. B. (I961). Cell aggregation in Dictyostelium discoideum. Developmental Biology 3, 725-756.

Konij, T. M., Barkley, D. S., Chang, Y. Y. \& Bonner, J. T. (I968). Cyclic AMP: a naturally occurring acrasin in the cellular slime moulds. American Naturalist ro2, 225-233.

Lin, Y. M., Liu, Y. P. \& Cheung, W. Y. (1974). Cyclic $3^{\prime}-5^{\prime}$-nucleotide phosphodiesterase. Purification, characterisation and active form of the protein activator from bovine brain. Journal of Biological Chemistry 249, 4943-4954.

Lowry, O. H., Rosebrough, N. J., Farr, A. L. \& Randall, R. J. (I95I). Protein measurement with the Folin phenol reagent. Journal of Biological Chemistry 193, 265-275.

Malchow, D., Fuchila, J. \& Nanjundiah, V. ( 1975 ). A plausible role for a membrane-bound cyclic AMP phosphodiesterase in cellular slime mold chemotaxis. Biochimica et biophysica acta $\mathbf{3 8 5}, 42 \mathrm{I}-428$.

Malchow, D. \& Gerisch, G. (1974). Short-term binding and hydrolysis of cyclic $3^{\prime}-5^{\prime}$-adenosine monophosphate by aggregating Dictyostolium cells. Proceedings of the National Academy of Sciences of the United States of America 7r, 2423-2427.

Malchow, D., NäGele, B., Schwarz, H. \& Gerisch, G. (I972). Membrane-bound cyclic AMP phosphodiesterase in chemotactically responding cells of Dictyostelium discoideum. European Journal of Biochemistry 28, I 36-1 42.

Malkinson, A. M. \& Ashworth, J. M. (1973). Adenosine $3^{\prime}-5^{\prime}$-cyclic monophosphate concentrations and phosphodiesterase activities during axenic growth and differentiation of cells of the cellular slime mould Dictyostelium discoideum. Biochemical Journal 134, 31 I-3 I 9.

Michal, G. \& Bergmeyer, H. V. (1970). In Methoden der Enzymatischen Analyse, 2nd edn, p. 2060. Edited by H. V. Bergmeyer. Weinheim: Verlag Chemie.

Newell, P. C. (197I). The development of the cellular slime mould Dictyostelium discoideum: a model system for the study of cellular differentiation. Essays in Biochemistry 7, 87-126.

RAPER, K. B. (1950). Pseudoplasmodium formation and organisation in Dictyostelium discoideum. Journal of the Elisha Mitchell Scientific Society 56, 241-282.

Riedel, V. \& GERISCH, G. (I97I). Regulation of extracellular cyclic-AMP-phosphodiesterase activity during development of Dictyostelium discoideum. Biochemical and Biophysical Research Communications 42, I I 9-1 24 .

Riedel, V., Gerisch, G., Müller, E. \& Beug, H. (1973). Defective cyclic adenosine-3'-5'-phosphatephosphodiesterase regulation in morphogenetic mutants of Dictyostelium discoideum. Journal of Molecular Biology 74, 573-585. 
Riedel, V., Malchow, D., Gerisch, G. \& Nägele, B. (1972). Cyclic AMP phosphodiesterase interaction with its inhibitor of the slime mould Dictyostelium discoideum. Biochemical and Biophysical Research Communications 46, 279-287.

Robertson, A., Drage, D. J. \& Cohen, M. H. (1972). Control of aggregation in Dictyostelium discoideum by an external periodic pulse of cyclic adenosine monophosphate. Science, New York r75, 333-335.

Roos, W., Nanjundiah, V., Malchow, D. \& Gerisch, G. (1975). Amplification of cyclic-AMP signals in aggregating cells of Dictyostelium discoideum. FEBS Letters 53, I39-I 42.

ShAFFER, B. M. (1956). Acrasin, the chemotastic agent in cellular slime moulds. Journal of Experimental Biology 33, 645-657.

ShafFer, B. M. (1957). Aspects of aggregation in cellular slime moulds. I. Orientation and chemotaxis. American Naturalist 91, I9-35.

Thompson, W. J. \& Appleman, M. M. (1971). Multiple cyclic nucleotide phosphodiesterase activities from rat brain. Biochemistry Io, 3I I-3I6.

Watts, D. J. \& Ashworth, J. M. (1970). Growth of myxamoeba of the cellular slime mould Dictyostelium discoideum in axenic culture. Biochemical Journal 119, 171-174. 